\title{
Distribution of a rare crane fly Ctenophora ornata Meigen, 1818 (Diptera, Tipulidae) in Poland
}

\author{
Marek BĄKOWSKI*, Damian BRUdER** and Wojciech PIĄTEK*** \\ *Department of Systematic Zoology, Institute of Environmental Biology, Mickiewicz University, \\ Umultowska89,61-614 Poznań; e-mail. bakowski@amu.edu.pl \\ **Wrocławska 21a/2 67-100 Nowa Sól \\ ** Chinów, Cztery Kopce 1/2 , 26-900 Kozienice
}

\begin{abstract}
New localities of a rare crane fly Ctenophora ornata Meigen, 1818 (Diptera, Tipulidae) in Poland are presented. Recent records, especially from western and northern parts of Poland, show that the species is more widespread than previously known.
\end{abstract}

Key words: Diptera, Tipulidae, Ctenophora ornata, new records, Poland

\section{INTRODUCTION}

Among the crane flies (Tipulidae), all the species of genus Ctenophora Meigen, 1803 are large and often ichneumon or wasp-like. The body is frequently polished and coloured black with large yellow, orange or red markings. The genus comprises ten species in the West Palaearctic. So far, five of them have been recorded from Poland and they are classified into the subgenus Cnemoncosis Enderlein, 1921: C. ornata Meigen, 1818 and C. factuosa Loew, 1871 and into the subgenus Ctenophora s. str.: C. flaveolata (Fabricius, 1794), C. guttata Wiedemann, 1818 and C. pectininicornis (Linnaeus, 1758) (Skibińska, Chudzicka 2007). All Ctenophora species are rare in Poland and are listed in the Red List of Threatened Animals in Poland (Palaczyk et al. 2002). Among the genus Ctenophora the rarest is C. ornata (Fig. 1) and this species is the only listed in the Polish Red Data Book of Animals with category vulnerable (Palaczyk 2004). C. ornata was found in Świętokrzyski National Park from Święty Krzyż (Kowalczyk \& Sliwiński 1988) and in the "Węże" forest reserve situated in Załęcze Landscape Park (Palaczyk 2004). In 2010, it was recorded from "Srebrne Źródła" National Preserve, Chrząstowice near Opole [UTM - BB91] (Hebda 2010).

C. ornata occurs in the deciduous forest zone of Europe. It was found in many countries: west of Ireland, Great Britain and Denmark to Spain and northern Italy, in east of the Czech Republic to Greece (including Andros and Corfu), Ukraine and the Turkish province of Içel (Oosterbroek et al. 2006). Surprisingly, the new version of Fauna Europaea (Oosterbroek 2009) does not list this species as present in Poland

\section{MATERIAL}

The new records of Ctenophora ornata Meigen, 1818 in Poland (Fig. 2) are:

- Nowa Sól (WT43): female and male were attracted to a light in old and abandoned

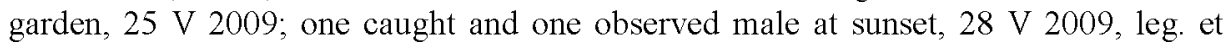
coll. D. Bruder;

- Gruszowa (FA20): one male caught on a light in VI 2007, leg. et coll. J. Mazepa; 
- Maciejowice-Cztery Kopce (EC31): one male caught on a light in 27 VII 2005, leg. W. Piątek, coll. M. Bakiowski;

- Kujan near Zlotów (XV41): one male was attracted to a light in an abandoned rural park, 6 VI 2007, leg. R. Rosa \& R. Ruta, coll. R. Rosa.

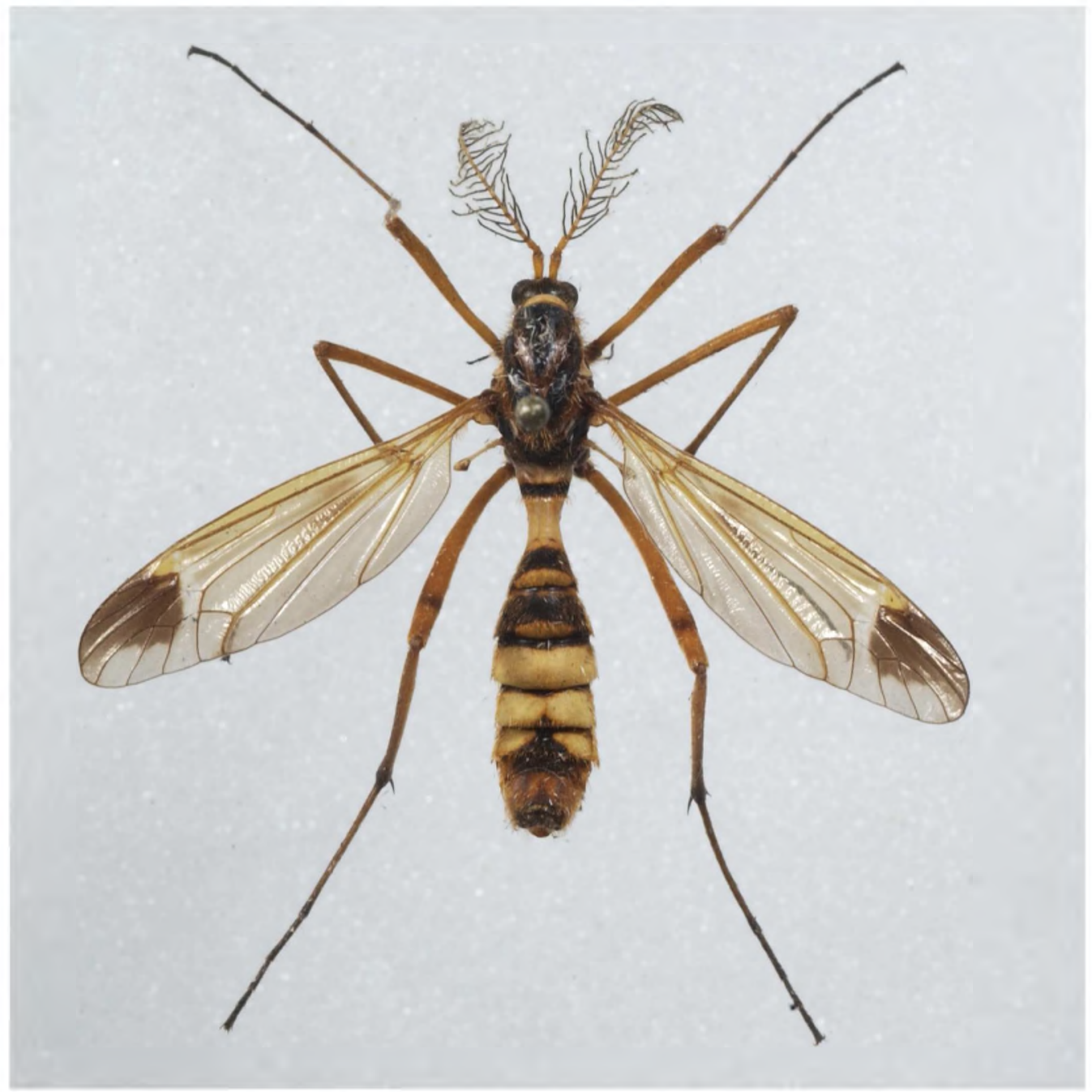

Fig. 1. Male of Ctenophora ornata, Maciejowice-Cztery Kopce, 27 Iuly 2005, leg. W. Piątek

\section{MORPHOLOGY AND BIOLOGY}

By the external characters $C$. ornata ( Fig. 1) is the closest to $C$. factuosa. Both species can be easily distinguished by the shape and the size of a spot in the apical part of wings and the coloration of the tibia of hind legs. The spot in the apical part of the wing of $C$. ornata is elongated, continuing broadly to the tip of the wing. The basal half of the tibia of the hind leg is not darkened nor is with darkened ring. The spot in the apical part of the wing of $C$. factuosa is rounded, not reaching the tip of the wing. The basal half of the tibia of the hind leg is darkened or is with darkened ring. Males of both species differ also in the shape of the 
hypopygium. The 8 th abdominal sternite in C. ornata males is enlarged and not closely aligned to the abdomen (Menier 1973, Savchenko 1973, Oosterbroek et al. 2006).

The adults of $C$. ornata fly from May to August, mainly in June and July. Larvae of all Ctenophora species develop in decaying wood of deciduous trees, mostly trees of big diameter and at the advanced stage of decay. They usually inhabit old forests, orchards and other habitats with the presence of old, dead and hollow trees. The larvae of this species develop in decaying wood of Fagus spp., Ulmus spp., Aesculus spp., Acer spp. and Malus spp. (Menier 1973, Savchenko 1973). Thus, presence of dead, dying and hollow trees has a substantial importance for all Ctenophora species; the only reports about their development come from

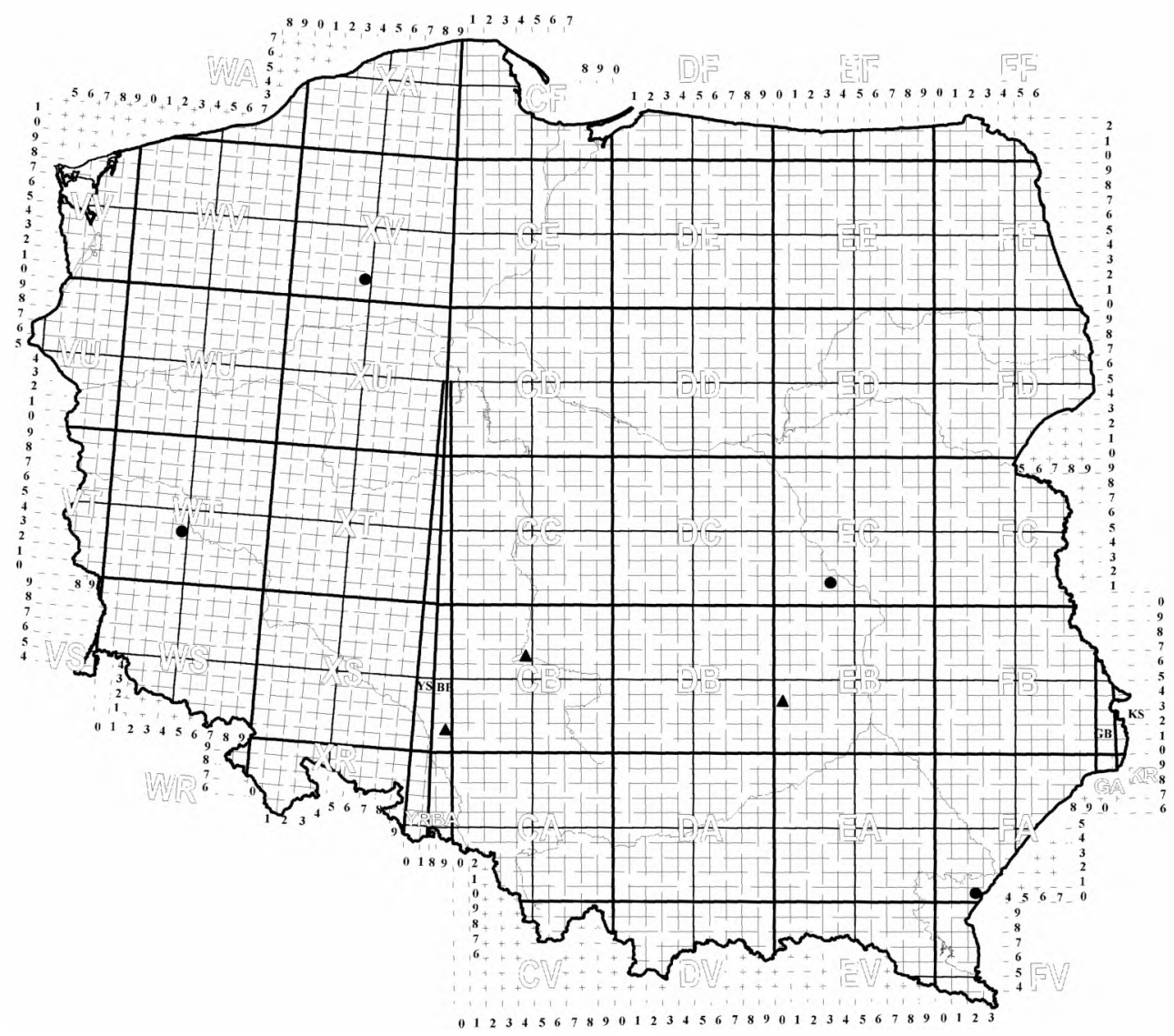

Fig. 2. Distribution of Ctenophora ornata in Poland: $\bullet-$ new records, $\wedge$ - literature data

CONCLUSIONS

In Poland this crane fly species has been hitherto known from south part of the country (Fig. 2). In recent years, the number of new records of this species have increased in Poland.

The new localities (particularly in the western and northern part of Poland) confirm wider occurrence in the country and form the north-eastern corner of the range limit of $C$. ornata in 
Europe. Despite the new localities found, the species is still very rare saproxylic fly in Poland. $C$. ornata is threatened with extinction in whole of its European range, mostly due to lost of the forest area of primeval character.

\section{ACKNOWLEDGEMENTS}

We are grateful for unpublished data on the distribution of C. ornata to J. Mazepa, R. Rosa, R. Ruta.

\section{REFERENCES}

HEBDA G. 2010. Xylomyia maculata (Meigen, 1804) (Xylomyiidae) and Ctenophora ornata Meigen, 1818 (Tipulidae) - new records of rare saproxylic flies (Diptera) from tree holes in Poland. Opole Scientific Society Nature Journal 43: 101-104.

KOWALCZYK J. K. \& ŚLIWIŃSKI Z. 1988. Uwagi o entomofaunie lądowej Świętokrzyskiego Parku Narodowego. Parki Narodowe i Rezerwaty Przyrody. 8: 33-39.

MenIER J. J. 1973. Les Ctenophorinae de France (Dipt. Tipulidae). Annales de la Société Entomologique de France (N. S.), 9 (4): 929-942.

Oosterbroek P., Bygebjerg R. \& Munk T. 2006. The West Palearctic species of Ctenophorinae (Diptera: Tipulidae): key, distribution and references. Entomologische Berichten, Amsterdam, 66 (5): 138-149.

OOSTERBRoEK P. 2009. Tipulidae. In: de JONG H. (ed.), Fauna Europaea: Diptera, Nematocera. Fauna Europaea, Version 2.1, online at http://www.faunaeur.org/ (updated 22 December 2009).

PalaczyK A., Soszyński B., Klasa A., Bystrowski C., Mkolajczak W. \& Krzemiński W. 2002. Diptera Muchówki In: Glowacníski Z. (ed.), Czerwona Lista Zwierząt Ginących i Zagrożonych w Polsce, pp. 38 - 44. Instytut Ochrony Przyrody PAN, Kraków, 156 pp.

PALACZYK A. 2004. Ctenophora ornata. In: GŁoWACIŃsKi Z. \& NowACKI J. (eds), Polska Czerwona Księga Zwierząt. Bezkręgowee, pp. 291-292. Instytut Ochrony Przyrody PAN, Kraków, 452 pp.

SAvChENKo E. N. 1973. Family Tipulidae. Subfamilies Tipulinae (Final Part) and Flabelliferinae. Fauna of the USSR, Diptera 2, 5 (N. S.). Nauka, Leningrad, 282 pp. [In Russian]

SkiBniska E. \& ChUdzickA E. 2007. Tipulidae: Diptera. In: BogdaNowicz W., ChudzICKA E., PILIPUK I. \& SKIBIŃSKA E. (eds), Fauna of Poland: Characteristics and checklist of species, Vol. 2, pp. 77-78. Muzeum i Instytut Zoologii PAN, Warszawa, 506 pp.

\section{STRESZCZENIE}

\section{[Rozsiedlenie rzadko spotykanej koziulki Ctenophora ornata Meigen, 1818 (Diptera, Tipulidae) w Polsce]}

Ctenophora ornata Meigen, 1818, z racji rzadkości występowania w naszym kraju, jako jedyna muchówka z Tipulidae została umieszczona w Polskiej Czerwonej Księdze Zwierząt. (Palaczyk 2004). Nowe stwierdzenia $C$. ornata, szczególnie w zachodniej i północnej Polsce, potwierdzają szersze występowanie tego gatunku w naszym kraju jak i w Europie (Fig. 2). Wszystkie okazy zostały zwabione do źródeł światła. W pracy podano również informacje o morfologii i biologii tej saproksylicznej muchówki. 